\title{
Human Interaction with Creators and Fellow Creatures (Study of Communication Relations of XYZ in Alamin Theory)
}

\author{
Muhammad Aminullah \\ Researcher at Kuala Lumpur's ICNS-ALAMTOLOGI, \\ aminullahtengku@gmail.com
}

\begin{abstract}
These studies are important to understand the process of interaction in human relations with the creator and also relationships with fellow creatures. The research method used is a qualitative research based on content analysis approach, with the aim to be able to explore the theory of alamin used in this study. The results found that interaction was formed by the existence of one of the most basic objectives in communication, namely necessity. This concept can be understood that everything needed by humans, then must have a process of relationships in the form of interaction to be able to achieve whatever objects are needed. But the interaction process is different. Therefore human interactions have two goals. First, human interaction with the creator called the relationship $X$ with $Y$. This interaction is carried out by $X$ to $Y$ in the form of a relationship as creator to $X$, provider of living facilities to $X$, trustee $Y$, and $X$ servant $Y$. Second is human interaction with the universe this is called the relationship $X$ with $Z$. This interaction is carried out by $X$ to $Z$ in the form of a $Z$ relationship as a reference for $X$, a provider of mass space for $X$, a power provider for $X$, and a proof of space for the implementation of the $X$ assignment.
\end{abstract}

Keywords: Interaction; human; creator; being; communication; Alamin

\section{Introduction}

Communication is a symbolic behavior that cannot be separated in human life. ${ }^{1}$ Communication also has existed since humans existed, so in this case communication becomes a necessity in his life. In addition, communication is also referred to as social interaction, because humans are social beings. Thus, the meaning of communication is one of daily activities that is truly connected with all human life. ${ }^{2}$ Meanwhile, according to B Aubrey Fisher, communication is the delivery of information, ideas, emotions, skills and others by using symbols, sounds, pictures, numbers and graphics. ${ }^{3}$

The relationship of human communication with non-humans, needs to be a part of the discussion in communication science, due to the basis of the necessity, such as the occurrence of human interaction with water, on the basis of human need for water. Apart from this, it is also necessary to understand that interaction is the initial process of communication. Basically interaction is a process of reciprocal relations carried out by individuals and individuals, between individuals and groups, between groups and individuals, between groups and groups in social life. In the Big Indonesian Dictionary it is explained that interaction is a matter of taking action, relating, influencing, between relationships. ${ }^{4}$

\footnotetext{
${ }^{1}$ Alo Liliweri, Komunikasi Serba Ada Serba Makna, Cet. 1, (Jakarta: Kencana, 2011), h. 47. Lihat Juga, Alo Liliweri, Makna Budaya Dalam Komunikasi Antarbudaya, (Yogyakarta: LKiS, 2002), p.8

${ }^{2}$ Stephen W. Littlejohn, terj: Mohammad Yusuf Hamdan, Teori Komunikasi, (Jakarta: Salemba Humanika, 2009) p. 3

${ }^{3}$ B. Aubrey Fisher, terj: Soejono Trimo, Teori-Teori Komunikasi, (Bandung: Remaja Karya, 1986) p. 10

${ }^{4}$ Tim Penyusun Kamus Pusat Bahasa, Kamus Besar Bahasa Indonesia, (Jakarta: Pusat Bahasa, 2002), p. 438
} 
Based on this understanding, interactions that occur between humans and the environment and also with the creator, need to be made a scientific study in communication science that is integrated with the discipline of ALAMTOLOGI so that the results of the study have values that can be applied in a real scientific, systematic and universal form.

As for a basic introduction to ALAMTOLOGI, it needs to be understood that ALAMTOLOGI is a new discipline that stands alone by referring to nature in nature. ALAMTOLOGI is knowledge that is applied by using nature as a reference. Thus ALAMTOLOGI becomes the science that studies about nature scientifically and systematically to make it as a reference of life for humans. ALAMTOLOGI proves the relationship between humans and nature scientifically and systematically. This knowledge was conceived by P. Alt Masa Bayu (P. i.A) whose full name is HA Zamre bin Ab Wahab, a scientist with a Malay national who had served as an advisor to the $5^{\text {th }}$ Prime Minister of Malaysia, namely Tun Abdullah Ahmad Badawi in the field of technology. This science is built by looking at the most basic origin, namely: 1) All creation of Allah SWT nothing is in vain, 2) Every event must be based on the right level, 3) Relationships occur on the basis of necessity, and 4) Making human relationships with nature in balance.

As the basis for thinking about the form of the communication process described in ALAMIN THEORY that can be understood based on the form Figure rajah 1.1 below.

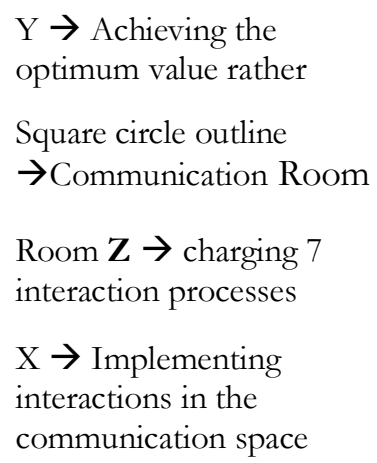

optimum value rather
Square circle outline
$\rightarrow$ Communication Room
Room $\mathbf{Z} \rightarrow$ charging 7
interaction processes
$\mathrm{X} \rightarrow$ Implementing
interactions in the
communication space

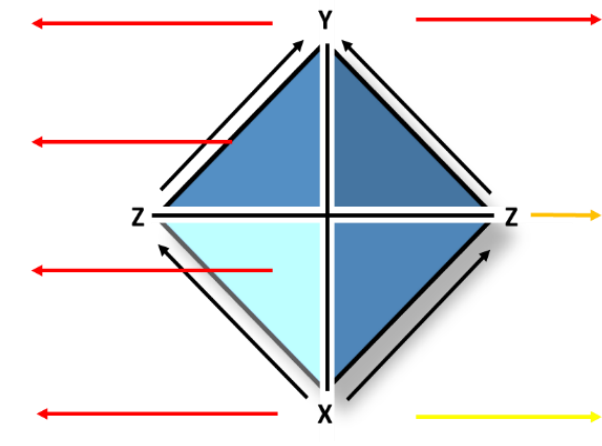

Purpose

Media

Executing

Figure 1. Basic Forms of Communication Thinking in ALAMIN THEORY5

Based on Figure rajah 1.1, it is necessary to understand that $\mathrm{X}$ can achieve communication with the optimum value to $\mathrm{Y}$, by means of $\mathrm{X}$ using $\mathrm{Z}$ space as a medium in conducting 7 interaction processes, with all the elements in the $\mathrm{Z}$ space. The $\mathrm{Z}$ room is a form of communication room. This proves that communication can be carried out only within the $\mathrm{Z}$ space limit. Therefore, based on the value of communication carried out by $\mathrm{X}$, it becomes the value achieved to $Y$. Achievement of that value is done through several processes of interaction carried out by $\mathrm{X}$ in the $\mathrm{Z}$ media. That, the study of interaction in human relations with the creator and also with living things, becomes the most important study that needs to be found in the science of communication. This is due to the need for openness of the scope of the study of communication to a wider space.

\footnotetext{
${ }^{5}$ Muhammad Aminullah, Theory of Alamin: A Formation of Universal Communication Formula, Budapest International Research and Critics Institute-Journal (BIRCI-Journal) Volume 1 No. 2, June 2018, (www.bircujournal.com/index.php/birci ) p. 174
} 


\section{Review of Literature}

\subsection{Interaction}

Understanding the meaning of interaction as explained by Hafied Cangara in his book, explains that, Gillin defines interaction as social relations in which concerns relationships between individuals, individuals and groups or between groups. According to Charles P. Loomis, mentioning a relationship can be called an interaction if it has the characteristics of the number of perpetrators of two or more people, there is communication between actors using symbols or symbols, there is a time dimension that includes past, present and future , and the goals to be achieved. ${ }^{6}$

As according to Wahyu Ilaihi in the Da'wah Communication book, it can be understood that interaction is an activity that enables the occurrence of a relationship between one person and another, which is then actualized through communication practices. While communication is one of the important conditions for the creation of interaction in people's lives. ${ }^{7}$ Based on understanding the occurrence of interactions on the basis of needs, it can be understood based on the easiest example that a student needs a lecturer signature for approval of thesis guidance. To get the signature, the student will prepare all materials for interaction. Interaction that is done is not just communication by contacting for permission to meet, but to prepare a study report paper, a sheet of endorsement, even the attitude and manners for him to meet his lecturers. This behavior is prepared to be accepted when meeting his lecturer with the aim of getting his signature.

\subsection{Human Relationship with the Creator}

The relationship between $\mathrm{X}$ and $\mathrm{Y}$ in the interaction is the relationship between the servant and the Creator. ${ }^{8}$ This relationship is an absolute relationship that cannot be broken. This means that the servant remains the position of servant of the Creator, even though in any condition it remains in its position and cannot be replaced. In this case, interaction must always occur, because I definitely need to the Creator.

The need for interaction in X's relationship with $\mathrm{Y}$ is never interrupted. If one moment is interrupted, then at that time also the relationship $\mathrm{X}$ with $\mathrm{Y}$. The interaction process in the relationship $\mathrm{X}$ with $\mathrm{Y}$ there are four processes, namely the interaction in the relationship $\mathrm{X}$ to $\mathrm{Y}$ as the creator of $\mathrm{X}$, the interaction in the relationship $\mathrm{X}$ to $\mathrm{Y}$ as the giver for $\mathrm{X}$, the interaction in relation $\mathrm{X}$ to $\mathrm{Y}$ as the executor of the mandate of $\mathrm{Y}$, and the interaction in relationship $\mathrm{X}$ in the position of servant $\mathrm{Y}$.

\subsection{Human Relations with Other Living Beans}

The relationship between $\mathrm{X}$ and $\mathrm{Z}$ in the most basic interaction is the relationship of others as creatures created by $\mathrm{Y}$. $\mathrm{X}$ must understand that the relationship with $\mathrm{Z}$ is the same as a creature. But on the other hand $X$ is in $Z$ space. If $Z$ does not exist then $X$ will not be created. Here actually $\mathrm{X}$ has an inseparable relationship with $\mathrm{Z}$. This is the actual concept of

\footnotetext{
${ }^{6}$ Hafied Cangara, M.Sc., Pengantar Ilmu Komunikasi, (Jakarta: Raja Grafindo Perkasa, 2007), p.1-2

${ }^{7}$ Wahyu Ilaihi, Komunikasi Dakwah, cet. 1, (Bandung: Remaja Rosdakarya, 2010), p. 131

${ }^{8}$ Hashim Ahmad Shiyuti, Ya! Islam Itu Mudah, Cet.1 (Selangor: Karangkraf, 2015), p. 62
} 
$\mathrm{X}$ having the main task of acting as the executor in the $\mathrm{Z}$ space. $\mathrm{X}$ has the task of carrying out all cases in the $\mathrm{Z}$ space to be able to provide optimum benefits to all $\mathrm{Z}$ spaces.

On the other hand it needs to be understood that if $X$ does not take the role of $X$ and also does not position $\mathrm{X}$ as $\mathrm{X}$, then surely the balance on $\mathrm{Z}$ will not apply. If $\mathrm{Z}$ is not balanced, then $\mathrm{Z}$ will apply damage. The damage that happened to $\mathrm{Z}$ must give the impression to $X$. Because $X$ does not maintain balance in $Z$. Thus it can be understood that the damage of $\mathrm{Z}$ is also the damage of $\mathrm{X}$. The balance of $\mathrm{X}$ with $\mathrm{Z}$ in forming a harmonious relationship, then the position of $\mathrm{X}$ with $\mathrm{Z}$ is $\mathrm{X}=\mathrm{Z}$. $\mathrm{X}=\mathrm{Z}$ is a formula used in ALAMTOLOGI to explain the harmony of nature's relationship with humans. If the relationship between $\mathrm{X}$ and $\mathrm{Z}$ is not balanced, then it is called $\mathrm{X}<\mathrm{Z}$. $\mathrm{X}<\mathrm{Z}$ is a formula used in ALAMTOLOGI to explain there is no harmony between nature and humans. This harmony is not caused by human behavior itself in taking the role of $X$ against $Z$. As $X$ is too greedy for $Z$, so the desire exceeds the capacity of $X$ itself at that time, then the excess outside the $\mathrm{X}$ 's capacity becomes damage to $\mathrm{Z}$. Finally the damage to $\mathrm{Z}$ returns to $\mathrm{X}$. So when $\mathrm{X}$ feels the damage is the response of $\mathrm{X}$ 's interaction done to $\mathrm{Z}$.

\subsection{Theory of Alamin}

ALAMIN THEORY is the science of communication ALAMTOLOGI. ${ }^{9}$ This theory explains that communication science has its own law and formula in explaining communication and its application. ALAMIN THEORY has a complete science with its philosophy, law and syllabus that may be practiced in the academic world and also during the period.

The ALAMIN THEORY is formed based on the phenomenon of the development of science about communication. but the phenomenon of communication science today has not been able to explain and apply forms of interaction that can be done to all non-human elements in harmony. The proof is the use of natural elements so far in the form of objects that do not pay attention to the value of mutual benefits between human and non-human relations. Thus, the world today clearly needs refinement in the angle of science and application in the aspect of communication. In fact, the problems and all the issues that are taking place throughout the world must turn back to the lameness of the implementation of life. Then the implementation of life is explained to X namely humans.

The ALAMIN THEORY formula can be seen in the following figure.

\footnotetext{
${ }^{9}$ Muhammad Aminullah, Theory of Alamin: A Formation of Universal Communication Formula, Budapest International Research and Critics Institute-Journal (BIRCI-Journal) Volume 1 No. 2, June 2018, (www.bircujournal.com/index.php/birci ) p. 165
} 


\section{$\mathrm{X}+\mathrm{Z}(\mathrm{Y}) \Leftrightarrow \mathrm{gHp}$ $X-Z(0) \Leftrightarrow g C p$}

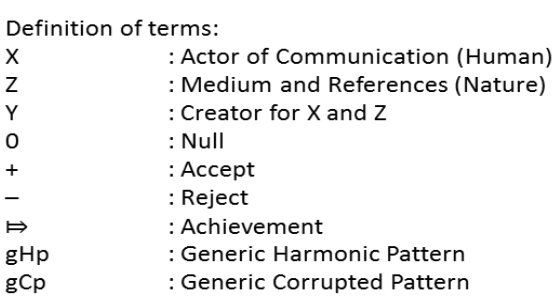

\section{Figure 2. Alamin Theory Formula ${ }^{10}$}

An explanation of this formula needs to be understood that XYZ interaction is the initial process for the formation of ALAMIN THEORY. This theory has its core point in the direct relationship of $\mathrm{X}$ with $\mathrm{Y} .{ }^{11}$ While $\mathrm{Z}$ is the media in connecting $\mathrm{X}$ to $\mathrm{Y}$. Therefore it can be understood that is the relationship of $\mathrm{X}$ with $\mathrm{Y}$ in the $\mathrm{Z}$ environment. The explanation of the ALAMIN THEORY formula can be understood that there are two forms of application, namely $\mathrm{X}+\mathrm{Z}(\mathrm{Y}) \Rightarrow \mathrm{gHp}$ and $\mathrm{X}-\mathrm{Z}(0) \Rightarrow \mathrm{gCp}$. The application form $\mathrm{X}+\mathrm{Z}(\mathrm{Y})$ is $\mathrm{X}$ received to make $Z$ as a reference in the interaction relationship, then $X$ can connect communication with $\mathrm{Y}$ in the form of harmony ( $\mathrm{gHp}$ ). While the application form $\mathrm{X}-\mathrm{Z}(0)$, namely $\mathrm{X}$ refused to make $\mathrm{Z}$ as a reference in the interaction relationship, then $\mathrm{X}$ cannot be connected to communication with $\mathrm{Y}$, this process is called limping (gCp). The achievement of $\mathrm{gCp}$, that is, $\mathrm{X}$ is empty, that is, it does not have a goal as a harmony value as the main goal that needs to be achieved rather than the communication. The use of $Z$ as a medium in connecting $\mathrm{X}$ with $\mathrm{Y}$ in ALAMIN THEORY has four fixed laws, namely $\mathrm{Z}$ as a position, $\mathrm{Z}$ as a process of recognition, $\mathrm{Z}$ as the outcome of an iyarah (signal), and $\mathrm{Z}$ as a survival (source of life). Thus, $X Y Z$ interactions can occur if $X$ sticks to the $Z$ media to be connected to $Y$. The interaction law in ALAMIN THEORY there are four namely interaction used on $X$, interaction applies only in the $\mathrm{Z}$ environment, the interaction process has $\mathrm{Z}$ as a reference, and interactions can be bring added value for $X$.

\section{Research Method}

This research is a communication research that collaborates between the study of communication with the ALAMTOLOGI approach based on the values of nature in the environment, which are formed in one concept, namely Theory of Alamin. But the goal of the study is related to communication that has the value of human interaction with the creator and

\footnotetext{
${ }^{10}$ Muhammad Aminullah, Formula Alamin: Alamtologi Communication, Budapest International Research and Critics Institute-Journal (BIRCI-Journal) Volume 1 No. 4, December 2018, (www.bircujournal.com/index.php/birci ) h. 51, Lihat juga, Muhammad Aminullah, Komunikasi Alamtologi-ALAMIN, Jilid I, (Kuala Lumpur: Nature Pattern Resources Sdn. Bhd, Cet. 1, 2018) p. 467

${ }^{11}$ Muhammad Aminullah, Alamtologi: Interaksi Manusia Dengan Air, Jilid I, (Kuala Lumpur: Nature Pattern Resources Sdn. Bhd, Cet. 1, 2017) p. 8
} 
also with all living things. Therefore this study is related to two aspects. First, the human relationship with the creator, and second, the aspects of the interaction of human relations with living things. These two aspects are explained using the ALAMTOLOGI foundation.

\section{Discussion}

\subsection{Xyz Interaction in the Concept of Alamin Theory}

The interaction in the XYZ relationship is the formation of relationships to make a basic process in producing an interaction. Interaction occurs because of the relationship between one element and another. Interaction is the process of mutual relations between one another on the basis of needs. Thus, the interaction is built on the basis of the need. So every whatever is needed in life, must to get these needs based on the results of interaction. Therefore, interaction is not limited to one element, but interaction can be done with all the elements that exist on the basis of the need for these elements.

The interactions in the XYZ relationship are divided into two namely the relationship $X$ with $\mathrm{Y}$ and the relationship $\mathrm{X}$ with $\mathrm{Z}$. The process of interaction in the XYZ relationship can be seen in the following figure.

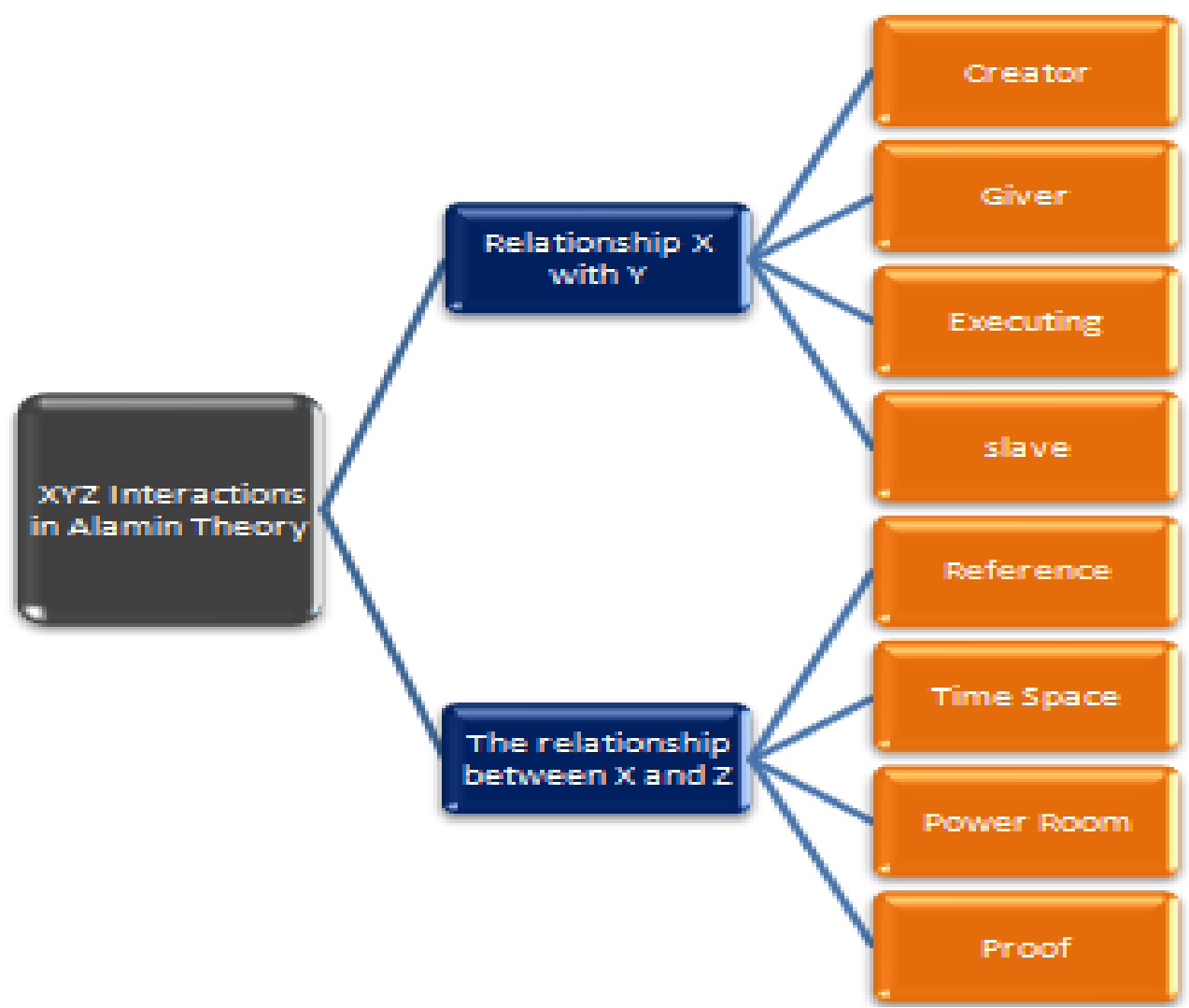

Figure 3. Interaction Process in XYZ Relations 


\subsection{Relationship X with $Y$}

The relationship between $\mathrm{X}$ and $\mathrm{Y}$ in the interaction based on this study has four main relationships, namely the interaction in the relationship $\mathrm{X}$ to $\mathrm{Y}$ as the creator of $\mathrm{X}$, the interaction in the relationship $\mathrm{X}$ to $\mathrm{Y}$ as the giver for $\mathrm{X}$, the interaction in the relationship $\mathrm{X}$ to $\mathrm{Y}$ as the executor of the mandate of $\mathrm{Y}$, and the interaction in relation $\mathrm{X}$ to the position of servant $\mathrm{Y}$.

\subsubsection{Creator}

The interaction in $\mathrm{X}$ 's relationship with the creator can be understood, namely the process of interaction carried out by $\mathrm{X}$ to $\mathrm{Y}$ for the need to know the creator for himself $\mathrm{X}$. This is very important for $\mathrm{X}$ to recognize $\mathrm{Y}$ that $\mathrm{X}$ is subject to the rules and mandate of the creator given to $X$. By understanding the needs of $X$ 's interaction with $Y, X$ knows that $X$ cannot be separated from its relationship with Y. This is where various kinds of efforts appear to be made by $\mathrm{X}$ to be able to maintain good interactions.

The interaction of $\mathrm{X}$ to $\mathrm{Y}$, that is, $\mathrm{X}$ must understand that the process of event $\mathrm{X}$ is regulated by $\mathrm{Y}$ through $\mathrm{Z}$. The form of interaction that can be applied by $\mathrm{X}$ in relation to $\mathrm{Y}$ as the creator is that $\mathrm{X}$ can protect $\mathrm{X}$ from the creation of $\mathrm{X}$ that has been made by $\mathrm{Y}$ in the form perfect. There are two ways to apply this interaction, namely maintaining the integrity of X's soul and preserving the integrity of $\mathrm{X}$ 's body as created by $\mathrm{Y}$ in a very good form. Maintaining wholeness in body and soul is guarding against the causes of damage to soul $\mathrm{X}$ and body X. As for the form of interaction with $\mathrm{Y}$ in maintaining the integrity of the soul well in self $\mathrm{X}$ as has been created by $\mathrm{Y}$ perfectly, there are four namely using reason to find ideologies that good, think about the needs that need to be cultivated, guarding the heart rather than the influence of water lust that is not appropriate to the needs, and avoid the use of emotions to achieve desires alone.

\subsubsection{Giver}

Discussion of the interaction process in the relationship between $\mathrm{X}$ and $\mathrm{Y}$ as the giver of $\mathrm{X}$, namely $\mathrm{Y}$ has the most important role as the giver of life for $\mathrm{X}$. In this case $\mathrm{Y}$ as the giver of all sources of life for $\mathrm{X}$, meaning $\mathrm{Y}$ has given $\mathrm{X}$ to be able to live and $\mathrm{Y}$ also gives all the resources that can make $X$ survive. The form of interaction in this explanation is found in the relationship $\mathrm{X}$ with $\mathrm{Y}$ in giving life and all living facilities by $\mathrm{Y}$ to $\mathrm{X}$.

The value of interaction in X's relationship with $\mathrm{Y}$ is in $\mathrm{X}$ 's acceptance of everything $\mathrm{Y}$ has given to $\mathrm{X}$. This is where an attitude of adequacy is born in all that is found based on the results of his efforts. Other languages mentioned are grateful for the results found based on the results of his efforts and always try to improve to improve the business.

The real form of interaction in this peel is to keep everything $\mathrm{Y}$ has given to $\mathrm{X}$, because $\mathrm{Y}$ is the source of the giver. The application of interaction in the form of maintaining everything that has been given by $\mathrm{Y}$, there are two, namely maintaining the integrity of life well and maintain living facilities properly. The interaction in maintaining the integrity of life for $\mathrm{X}$ there are four ways, namely maintaining the perfect body shape as has been given by $\mathrm{Y}$ to $\mathrm{X}$ in perfect form, maintaining the safety of life for himself $\mathrm{X}$ from the case that endangers his life, maintaining the period that has been given to $X$ by utilizing the available age as well as possible to provide benefits to others, and using the energy given by $\mathrm{Y}$ to $\mathrm{X}$ to be able to work and strive to be a benefit for themselves and others. 


\subsubsection{Implementing}

Discussion of the interaction process in $\mathrm{X}$ 's relationship with $\mathrm{Y}$ as the executor of the assignment and mandate of $\mathrm{Y}$ given to $\mathrm{X}$ ie $\mathrm{X}$ must be willing to carry out on the assignment and mandate given by $\mathrm{Y}$. In this case $\mathrm{X}$ becomes the executor to do all the tasks that have been mandated by $\mathrm{Y}$ to $\mathrm{X}$. $\mathrm{X}$ is assigned an assignment, because $\mathrm{X}$ has the right capacity to carry out the assignment.

The form of interaction $\mathrm{X}$ to $\mathrm{Y}$ as the executor is contained in the implementation of $\mathrm{X}$ in carrying out the assignments and the mandate given by $\mathrm{Y}$ to $\mathrm{X}$. The implementation of the assignment and mandate is a real form of interaction carried out by $\mathrm{X}$ on the direction of $\mathrm{Y}$. If $\mathrm{X}$ does not carry out the assignment and mandate given by $\mathrm{Y}$ to $\mathrm{X}$, then $\mathrm{X}$ interrupted the interaction with $\mathrm{Y}$ as the implementation of the assignment and mandate given by $\mathrm{Y}$. This can be seen in the example $\mathrm{Y}$ gave the mandate to $\mathrm{X}$ to maintain health and cleanliness of the body and the environment. If $X$ carries out these directives, then $X$ gets life safety in terms of health and hygiene. As for if $\mathrm{X}$ did not carry out these directives such as smoking, overeating and suction bye, and then surely $\mathrm{X}$ will get damage to him and become bad luck in life so that various diseases emerge. Thus it can be understood that the damage done to him is not a gift from $\mathrm{Y}$ to $\mathrm{X}$, but is caused by $\mathrm{X}$ 's own choice of not positioning himself $\mathrm{X}$ as the executor of the given assignment and mandate.

\subsubsection{Servant}

The form of interaction in the relationship of $\mathrm{X}$ with $\mathrm{Y}$ as a servant for $\mathrm{Y}$ is $\mathrm{X}$ always get along in carrying out all the commands that have been arranged by $\mathrm{Y}$ to $\mathrm{X}$ in everyday life. X's accuracy of Y's orders is a form of interaction carried out by $\mathrm{X}$ in positioning himself $\mathrm{X}$ as a servant to $\mathrm{Y}$. Thus, $\mathrm{X}$ has a capacity based on the position owned by the $\mathrm{X}$ person. The position of $\mathrm{X}$ will determine the capacity owned by $\mathrm{X}$, then the capacity will be an increase in position for $\mathrm{X}$, and so on. Based on this it can be understood that the position with the capacity can be increased by $\mathrm{X}$ for the work done by $\mathrm{X}$. However, no matter how high the position and the capacity is increased by $\mathrm{X}$, the position of $\mathrm{X}$ for $\mathrm{Y}$ is to remain eternal as a servant of Y.

The form of the interaction process that can be applied by $\mathrm{X}$ to $\mathrm{Y}$ as a servant of $\mathrm{Y}$ is that $\mathrm{X}$ must always do all the directions given by $\mathrm{Y}$ by placing the fixed $\mathrm{X}$ position on capacities as servants. Thus, the process of applying the interaction between $\mathrm{X}$ and $\mathrm{Y}$ as servants of $Y$ there are two forms namely placing $X$ as servants of $Y$ and understanding that the capacities of $X$ remain eternal as servants of $Y$. How to apply interactions in placing $X$ as servants of $\mathrm{Y}$ has four ways namely $\mathrm{X}$ can position itself as a creature made by $\mathrm{Y}$ in full, position $\mathrm{X}$ in a perfect position because $\mathrm{X}$ has been created as a perfect creation, $\mathrm{X}$ 's position as a servant then $\mathrm{X}$ must submit to all the rules set by $\mathrm{Y}$, and the last is the position of $\mathrm{X}$ to be a servant who obeys $\mathrm{Y}$ and is afraid of denying the rules set by $\mathrm{Y}$.

\subsection{Relationship $X$ with $Z$}

The relationship between $\mathrm{X}$ and $\mathrm{Z}$ in the most basic interaction is a fellow relationship as a creature created by $\mathrm{Y}$. The interaction that can be done by $\mathrm{X}$ to $\mathrm{Z}$ in undergoing the relationship between $\mathrm{X}$ and $\mathrm{Z}$, there are four forms, namely $\mathrm{X}$, making $\mathrm{Z}$ as a reference in implementation, $\mathrm{X}$ must understand existence in the space of time $\mathrm{Z}, \mathrm{X}$ must understand that in the process of life using the power of $\mathrm{Z}$, and $\mathrm{X}$ must understand that $\mathrm{Z}$ is able to prove all 
the things done by $\mathrm{X}$ correctly, because $\mathrm{Z}$ cannot cheat. The explanation of the four forms of interaction in the relationship $\mathrm{X}$ with $\mathrm{Z}$ as follows.

\subsubsection{Reference}

The form of interaction carried out by $\mathrm{X}$ to $\mathrm{Z}$ as a reference for $\mathrm{X}$, that is, $\mathrm{X}$ must always look at the facts in $\mathrm{Z}$ by reading all that is in $\mathrm{Z}$, looking for further evidence to understand all the cases in $\mathrm{Z}$ and applying to their understanding. Thus it can be understood that the form of interaction between $\mathrm{X}$ and $\mathrm{Z}$ as a reference for $\mathrm{X}$ is that every application made by $X$ must see and understand the concepts that exist in Z. Every element and change that applies to $\mathrm{Z}$ is based on the right facts. Therefore, every fact that is in $\mathrm{Z}$, will be evidence to be understood by $X$. For example, if it rains in an area, then all these areas will be flat all rain. Likewise this becomes a reference for $X$, so if $X$ does something beneficial to one group, then there is no difference between these individuals based on the capacity of each individual.

\subsubsection{Time Space}

The form of the process of interacting with time by $\mathrm{X}$ in the existing time space on $\mathrm{Z}$ there are four namely $\mathrm{X}$ can interact with $\mathrm{Z}$ in the form of using morning time for the beginning of the activity, $X$ can use daylight for the middle of the activity, $X$ can use evening time for the end in activity on that day, and $X$ can use the night to rest. Thus it can be understood that the interaction of the use of time $\mathrm{Z}$ that can be done based on the capacities of $\mathrm{X}$ has four parts namely morning, afternoon, evening and night. The use of these four times by $\mathrm{X}$ is a form of interaction carried out by $\mathrm{X}$ over the use of time $\mathrm{Z}$. The form of the explanation can be seen in Figure 4.4 below.

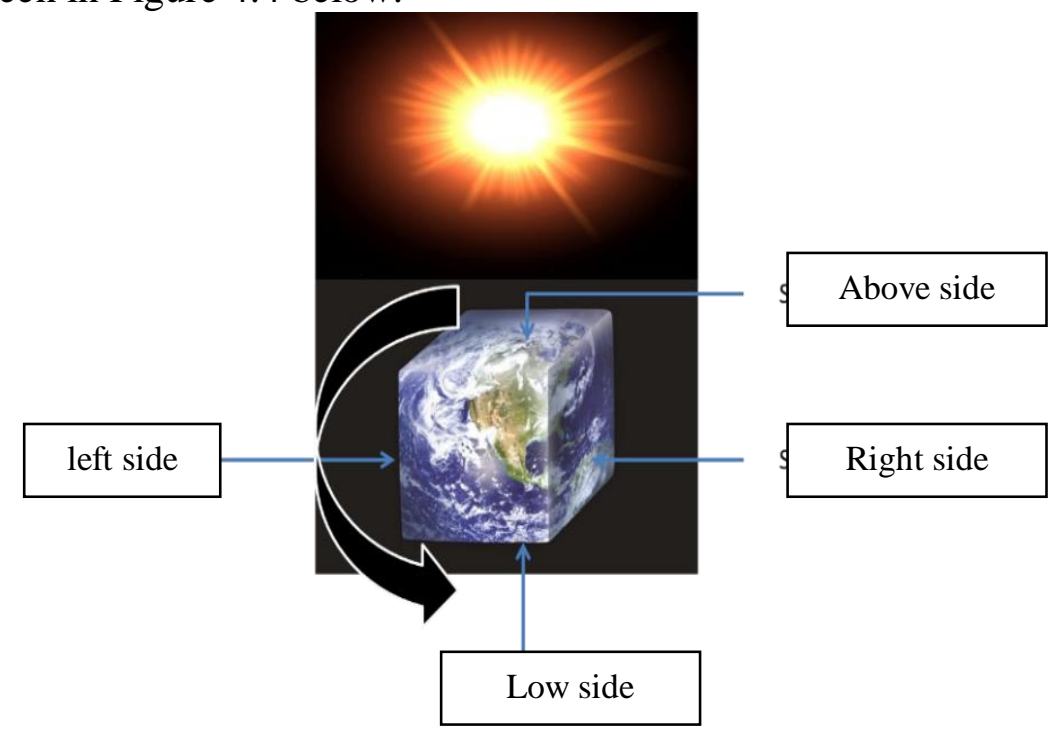

Figure 4. Capacitor X on Time Usage in Period Z

The application form of interaction based on position in the relationship $\mathrm{X}$ with $\mathrm{Z}$ can be done in four ways namely $X$ can use the future space in front to walk, $X$ can use the back time space to retreat, $X$ can use the time space left to shift to the left side, and $X$ can use the 
right time space to shift to the right side. This interaction is carried out with the form of the use of position in the mass space by $X$ to make motion in space $Z$. The four forms of movement $\mathrm{X}$ namely the front, back, left and right, which are in the $\mathrm{Z}$ space can be seen in Figure 4.5 below.

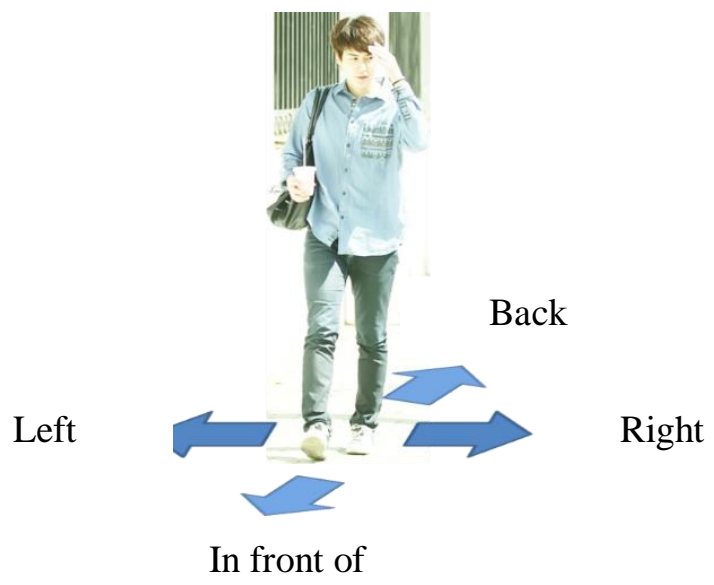

Figure 5. Use of Position X by Time Z in Space for Movement

Based on Figure 5 it can be understood that the form of interaction between $\mathrm{X}$ and $\mathrm{Z}$ is the process of using the position of the $\mathrm{Z}$ space for movement that can be carried out by $\mathrm{X}$ based on four time positions. The four positions of time space are the use of time space in the front position, the use of time space in the back position, the use of time space in the left position and the use of time space in the right position. The form of the application of the use of mass space on interactions in the relationship $\mathrm{X}$ with $\mathrm{Z}$ is that $\mathrm{X}$ can carry out activities in the process of life's journey $X$ and the location of the place as position $X$ by means of using the position and time in space $\mathrm{Z}$ appropriately based on the capacity possessed by $\mathrm{X}$. Then $\mathrm{X}$ can move on the capacity of $X$ itself in the use of time and position in the $Z$ space. This is a real form of application of $\mathrm{X}$ interaction in the use of $\mathrm{Z}$ space.

\subsubsection{Use of Energy}

The form of the interaction process in the use of power $\mathrm{Z}$ by $\mathrm{X}$ can be found in two parts, namely the use of power in the form of macro and the use of power in the form of micro. The application process of interaction in the use of macro power on the relationship of $\mathrm{X}$ with $\mathrm{Z}$ has four ways, namely the use of macro fellow humans in combining power for cooperation, $\mathrm{X}$ uses animal macro power to help $\mathrm{X}$ work such as the use of buffalo for rice plows, $\mathrm{X}$ uses macro power to grow plants for the use of benefits for $\mathrm{X}$ such as using wood to make a house, and $\mathrm{X}$ uses the macro power of the universe to make additional energy for $\mathrm{X}$ such as using solar power to help develop electricity for life $X$. The process of interaction in the use of macro $\mathrm{Z}$ power can be seen in the picture 4.6 follows. 


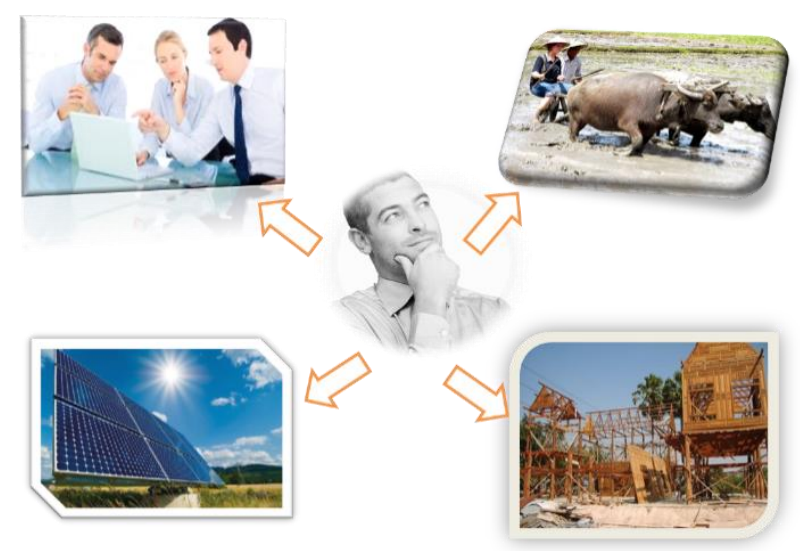

Figure 6. Use of Z Macro Power in Interaction

The interaction application process in the use of micro power on the relationship X with $\mathrm{Z}$ also has four ways, namely: -

a. $\mathrm{X}$ uses the $\mathrm{Z}$ micro-energy that is in $\mathrm{X}$ 's inner self such as the power of the hand to move, the power of the foot to walk, the power of the eye to see and all the power present in each element of the $X$ self,

b. $\mathrm{X}$ uses the $\mathrm{Z}$ micro power present in the elements of the animal such as the walking foot camel's power motion to be a vehicle for $X$,

c. $\mathrm{X}$ uses the $\mathrm{Z}$ micro-power that is inside the plant elements such as making wooden planks and log to build $X$ 's house, and

d. $\mathrm{X}$ uses the $\mathrm{Z}$ micro-power that is in the elements of the universe such as morning sun which emits ultraviolet light to get power for $\mathrm{X}$.

\subsubsection{Proof}

The forms of proof of the real factors directly on the interaction made by $\mathrm{X}$ to $\mathrm{Z}$ there are four forms, namely;

a. Z has evidence that can be seen clearly on the results of the implementation carried out by $X$, such as $X$ cleans the river, then the water in the river can flow properly,

b. $\mathrm{Z}$ has evidence in hard form that can be directly held directly for the results of the interaction carried out by $\mathrm{X}$, such as X planting durian principal, then the magnitude of growing durian principal to bear fruit becomes concrete evidence of the form of interaction,

c. $\mathrm{Z}$ has proof on the actual filling of something for each object resulting from the interaction carried out by $\mathrm{X}$, such as $\mathrm{X}$ cooking rice, then the results of rice that are ready to be eaten become tangible evidence in the form of filling something real, and

d. $\mathrm{Z}$ has evidence of body $\mathrm{X}$ being a physically healthy body for the results of the interaction carried out by $\mathrm{X}$ in the form of maintaining health and hygiene. Healthy body is the result of interaction in the form of tangible evidence of the implementation of $\mathrm{X}$ in maintaining cleanliness and health. 
The forms of proof of the real but indirect factors of the interactions made by $\mathrm{X}$ to $\mathrm{Z}$ there are four forms, namely;

a. $Z$ has visible but not real evidence directly from the results of the interaction carried out by $\mathrm{X}$ to $\mathrm{Z}$, such as $\mathrm{X}$ constructing a beautiful environment, then $\mathrm{Z}$ produces air in beautiful, cool and clean temperatures. The result of the beautiful air is the result of the interaction carried out by $\mathrm{X}$ that appears real but is not real directly,

b. $\mathrm{Z}$ has evidence in liquid form but it is not real direct liquid, but can only be proven by feeling the results of the interaction carried out by $\mathrm{X}$, such as $\mathrm{X}$ can do to maintain the quality of clean water so it does not smell bad, so clean water does not smelling will appear real but not directly. Knowledge of cleanliness without a foul odor is understood by the use of the taste in the nose to find out about the smell,

c. $\mathrm{Z}$ has evidence in the form of non-tangible contents of the application produced by $\mathrm{X}$, such as $\mathrm{X}$ keeps a clean glass empty, so empty does not mean nothing, but empty is empty content, because in a glass space it is actually filled millions of invisible atomic elements seen, and

d. Z has evidence of tangible but indirect results of interaction in the form of proof of soul and mental rather than feelings and thoughts generated by $X$ in interacting with $\mathrm{Z}$, as $\mathrm{X}$ is always uncomfortable seeing garbage scattered around the environment, this is because $\mathrm{X}$ has a value of responsibility in maintaining damage to $\mathrm{Z}$.

\section{Conclusion}

Based on the explanation of human interaction with the creator and also with the creature based on the Alamin theory approach, it can be concluded that the interaction is formed by the existence of one of the most basic goals in communication, namely necessity. the need to become the nucleus in communication, this is caused, surely everything that is communicated, is caused by a need. Thus, this concept can be understood that everything that is needed by humans then must have a process of relationships in the form of interaction to be able to achieve whatever objects are needed. But the interaction process is different. Therefore human interactions have two goals. First, human interaction with the creator called the relationship $\mathrm{X}$ with $\mathrm{Y}$. This interaction is carried out by $\mathrm{X}$ to $\mathrm{Y}$ in the form of a relationship as creator to $X$, a relationship in the provider of living facilities to $X$, a relationship in the form of $X$ as the executor of the mandate of $Y$, and a relationship in the form of X servant to Y. Second, the interaction of humans with the universe is called the relationship of $\mathrm{X}$ with $\mathrm{Z}$. This interaction is carried out by $\mathrm{X}$ to $\mathrm{Z}$ in the form of $\mathrm{Z}$ relations as a reference for $X$, meaning that any implementation of $X$ must require the element $Z$ as its medium, the relationship to $\mathrm{Z}$ as the provider the mass space for $\mathrm{X}$, the relationship with $\mathrm{Z}$ as the power provider for $X$, and the proof of the implementation of the assignment $X$. 


\section{References}

Alo Liliweri, (2011) Komunikasi Serba Ada Serba Makna, Cet. 1, Jakarta: Kencana.

Alo Liliweri, (2002) Makna Budaya Dalam Komunikasi Antarbudaya, Yogyakarta: LkiS.

Amir, Mafri, (1999) Etika Komunikasi Massa Dalam Pandangan Islam, cet. 1, Jakarta: Logos.

Antoni, (2004) Riuhnya Persimpangan Itu: Profil dan Pemikiran Para Penggagas Kajian Ilmu Komunikasi, cet. 1, Solo: Tiga Serangkai.

Anwar, Jazanul, (1998) Ekologi Ekosistem Sumatera, Yogyakarta: Gadjah Mada University Press.

Audi, Robert, (1995) The Cambridge Dictionary of Philosophy. United Kingdom: Cambridge University Press.

B. Aubrey Fisher, (1986) terj: Soejono Trimo, Teori-Teori Komunikasi, Bandung: Remaja Karya,

Bagus, Lorens, (2000) Kamus Filsafat, Jakarta: Gramedia Pustaka Utama.

Bertens K, Etika,( 2007) Jakarta: Gramedia Pustaka Utama.

Brown, Lester R, (1995) Masa Depan Bumi, terj: Hermoyo, ed. 1, Jakarta: Yayasan Obor Indonesia.

Budyatna, Muhammad dan Leila Mona Ganim, (2012) Teori Komunikasi Antarpribadi, cet. 2, Jakarta: Kencana Prenada Media Group.

Bungin, Burhan, (2008) Sosiologi Komunikasi: Teori, Paradigma, dan Diskursus Teknologi Komunikasi di Masyarakat, cet. 3, Jakarta: Prenada Media Group.

Cangara, H. Hafied, (2009) Pengantar Ilmu Komunikasi, ed. 1, Jakarta: Rajawali Pers.

Cangara, H. Hafied, (2007) Pengantar Ilmu Komunikasi, Jakarta: Raja Grafindo Perkasa.

Chandra, Budiman, (2006) Pengantar Kesehatan Lingkungan, cet. 1, Jakarta: EGC.

Cox, Robert, (2016) Environmental Communication and The Public Sphare, ed. 4, Washington DC: A Sage Reference Publication.

HA Zamre, (2013) Modul ALAMTOLOGI: Pengenalan ALAMTOLOGI, jld. 1, Kuala Lumpur: Nature Pattern Resources Sdn. Bhd.

Hady, M. Samsul, (2007) Islam Spiritual Cetak Biru Keserasian Eksistensi, Malang: UIN Malang Press.

Hafied Cangara, M.Sc., (2007) Pengantar Ilmu Komunikasi, Jakarta: Raja Grafindo Perkasa.

Hashim Ahmad Shiyuti, (2015) Ya! Islam Itu Mudah, Cet.1 Selangor: Karangkraf.

Husayni, Sayyid Muhammad Beheshti, (2002) Selangkah Menuju Allah: Penjelasan AlQur`an Tentang Tuhan, terj: Apep Wahyudin, cet. 1, Jakarta: Pustaka Zahra.

Ibrahim, I. A, (2010) Petit Guide Illustre Pour Comprendre L'Islam, London: Darussalam, th.

Ilaihi, Wahyu, Komunikasi Dakwah, cet. 1, Bandung: Remaja Rosdakarya.

Julianto, Tatang. S, (2015) Biokimia: Biomolekul Dalam Perspektif Al-Qur`an, ed. 1, cet. 1, Yogyakarta: Deepublish.

Jumantoro, Totok, (2001) Psikologi Dakwah Dengan Aspek-Aspek Kejiwaan yang Qur`ani, $\mathrm{ttt}:$ Amzah.

Keraf A. Sonni, (2010) Etika Lingkungan Hidup, Jakarta: Kompas Media Nusantara.

Kholil, Syukur, (2007) Komunikasi Islami, Bandung: Citapustaka Media.

Kodoatie, Robert J. dan Roestam Syarief, (2010)Tata Ruang Air, Ed. 1, Yogyakarta: Andi. 
Koncoro, Eko Budi, (2012) Aquascape: Pesona Taman Aquarium Air Tawar, cet. 5, Yogyakarta: Kanisius.

Kristanto, (2002) Philip, Ekologi Industri, Ed. 1, Cet. 1, Yogyakarta: ANDI.

Lasswell, (1948) Harold Dwight, The Structure and Function of Communication in Society. The Communication of Ideas. New York: The State University.

Lettlejohn, Stephen W, Karen A. Foss, Encyclopedia of Communication Theory, Washington DC: A Sage Reference Publication, tt

Lettlejohn, Stephen W, Karen A. Foss, (2011) Theories of Human Communication, ed. 10, USA: Waveland Press.

Lettlejohn, Stephen W, (2009) Teori Komunikasi, terj: Mohammad Yusuf Hamdan, Jakarta: Salemba Humanika.

Lubis, Suwardi, Teori-Teori Komunikasi: Sebuah Konsepsi, Analisa dan Aplikasi, Diktat Mengajar dan tidak dipublikasikan.

Machdar, Izarul, (2010) Ekologi Dan Pencemaran Lingkungan, cet. 1, Bandung: Citapustaka Media Perintis.

Mufid, Muhamad, (2009) Etika dan Filsafat Komunikasi, cet. 1, Jakarta: Kencana.

Muhammad Aminullah, (2017) Alamtologi: Interaksi Manusia Dengan Air, Jilid I, Kuala Lumpur: Nature Pattern Resources.

Muhammad Aminullah, (2018) Formula Alamin: Alamtologi Communication, Budapest International Research and Critics Institute-Journal (BIRCI-Journal).

Muhammad Aminullah, Komunikasi Alamtologi - ALAMIN, Jilid I, Kuala Lumpur: Nature Pattern Resources Sdn. Bhd, Cet. 1, 2018

Muhammad Aminullah, (2018) Theory of Alamin: A Formation of Universal Communication Formula, Budapest International Research and Critics Institute-Journal (BIRCIJournal)

Muis, Andi Abdul, (2001) Komunikasi Islami Bandung: Remaja Rosdakarya.

Mulyana, Deddy, (2001) Ilmu Komunikasi: Suatu pengantar, cet. 2, Bandung: PT. Remaja Rosdakarya.

Stephen W. Littlejohn, (2009) terj: Mohammad Yusuf Hamdan, Teori Komunikasi, Jakarta: Salemba Humanika.

Tim Penyusun Kamus Pusat Bahasa, (2002) Kamus Besar Bahasa Indonesia, Jakarta: Pusat Bahasa.

Wahyu Ilaihi, (2010) Komunikasi Dakwah, cet. 1, Bandung: Remaja Rosdakarya. 